\title{
Community-managed conservation efforts at Tsingy Mahaloka/KOFAMA, northern Madagascar: Right place at the wrong time?
}

Ian C. Colquhoun
Correspondence:

Ian C. Colquhoun

Department of Anthropology, The Centre for Environment \& Sustainability, The University of Western Ontario.

London N6A 5C2 - Canada

E-mail: colquhou@uwo.ca

\section{RÉSUMÉ}

\section{ABSTRACT}

This paper provides a retrospective account of efforts, from 2007 to 2013 , to establish a community-managed protected area just south of Ankarana National Park that would encompass the limestone massif known locally as Tsingy Mahaloka and adjacent remnant forest patches. Community members of the rural commune of Antsiravibe came together in 2007 and, with support from the Peace Corps, formed KOFAMA (Koperativa Fikambanana Ankarabe Mitsinjo Arivo) to oversee management of the Tsingy Mahaloka site. When KOFAMA was initially established, Tsingy Mahaloka was envisioned as an ecotourist destination. Ecotourism is a pillar of the new IUCN "Lemurs of Madagascar" conservation action plan (2013-2016), and can allow rura communities to (i) secure revenue for habitat protection; (ii) create economic incentives and benefits for residents; and, (iii) facilitate locally-supported conservation efforts. Ecotourism to Tsingy Mahaloka was seen as a means for future sustainable development in the area. KOFAMA, as the local organization to be responsible for management of the protected area, was intended to operate by a "bottom-up" approach, where local stakeholders take active participation and leadership in decision-making affecting the protected area. But, obviously, an ecotourist site needs tourists; this has proven to be a problem for KOFAMA and the Tsingy Mahaloka site. The Tsingy Mahaloka site, on the face of it, would appear to offer much that would attract and educate ecotourists, including: striking topography (the massif's sheer limestone cliffs rising 80-100 metres above a flat coastal plain), a diverse endemic avifauna, a resident crowned lemur population, and extensive caves containing human burials made over generations. However, the site's relatively remote location and Madagascar's recent political crisis have worked against Tsingy Mahaloka becoming established as a site that ecotourists regularly visit. Regardless, a core group of local residents remain committed to the project's original goals. At this point in KOFAMA's history, however, an initial assessment of the organization draws attention to the limits of a "build it and they will come" approach to ecotourism, sustainable development, and locally-managed conservation efforts. The struggles encountered by KOFAMA in its efforts to oversee the Tsingy Mahaloka site highlight the importance of detailed ethnographic and socioeconomic work prior to embarking on such locally-managed conservation efforts.
Le présent compte rendu porte sur une rétrospective des efforts déployés de 2007 à 2013 pour établir une aire protégée au sud du Parc National de l'Ankarana et qui concerne le massif calcaire du Tsingy Mahaloka ainsi que ce qu'il reste de forêt sur sa périphérie. En 2007, les membres de la communauté de la commune rurale d'Antsiravibe se sont organisés avec le soutien des volontaires du Corps de la Paix pour former le KOFAMA (Koperativa Fikambanana Ankarabe Mitsinjo Arivo) afin de superviser le site du Tsingy Mahaloka reconnu comme une aire à protéger par la communauté. Lorsque KOFAMA a été initialement établi, le Tsingy Mahaloka avait été retenu comme une destination écotouristique. L'écotourisme est d'ailleurs un pilier du nouveau plan d'action de conservation des lémuriens de Madagascar de I'UICN pour la période 2013-2016. L'écotourisme est ainsi proposé aux communautés rurales de la périphérie des aires protégées comme un moyen de sécuriser des revenus en échange de la protection de l'habitat, mais aussi un moyen de proposer des incitations économiques et des avantages pour les résidents, et qui sont supportés localement. L'écotourisme lié au Tsingy Mahaloka a été considéré comme une activité de développement durable qui s'inscrit dans l'avenir de la région. KOFAMA, en tant qu'organisation locale responsable de la gestion de l'aire protégée est destiné à fonctionner selon une approche de bas en haut dans laquelle les acteurs locaux s'engagent réellement et dirigent les prises de décisions affectant l'aire protégée. Mais, de toute évidence, le processus a besoin de touristes, ce qui a constitué un problème pour KOFAMA et le Tsingy Mahaloka. À première vue, le Tsingy Mahaloka semble offrir de nombreuses caractéristiques propres à attirer et éduquer des écotouristes, dont une topographie remarquable avec des falaises calcaires abruptes de 80-100 mètres de haut dominant une plaine côtière, une avifaune endémique variée, une population résidente de Lémurs couronnés et des grottes abritant des sépultures humaines déposées par plusieurs générations. Mais, non seulement le Tsingy Mahaloka est-il relativement isolé, mais la crise politique de 2009 à 2014 Madagascar a également joué groupe de gens motivés poursuit les premiers objectifs du projet. À ce stade de I'histoire de KOFAMA, une évaluation initiale de I'organisation montre les limites d'une approche du type enfin une structure destinée à faciliter les efforts de conservation contre le développement de l'écotourisme. Malgré cela, un 


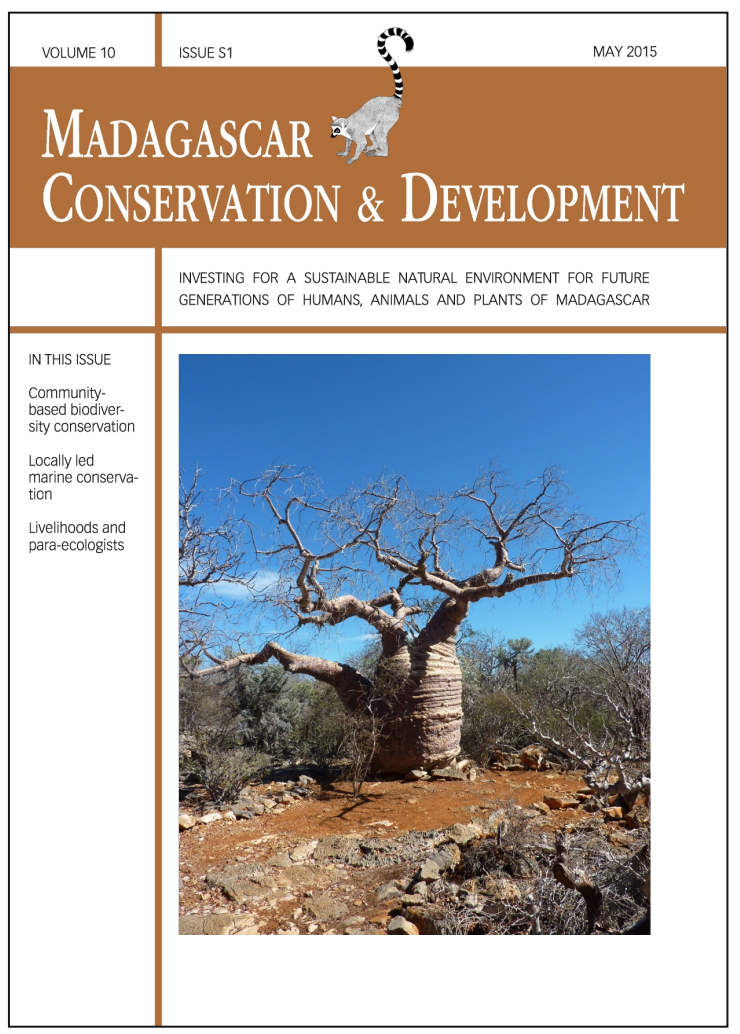

Madagascar Conservation \& Development is the journal of Indian Ocean e-Ink. It is produced under the responsibility of this institution. The views expressed in contributions to MCD are solely those of the authors and not those of the journal editors or the publisher.

All the Issues and articles are freely available at http://www.journalmcd.com

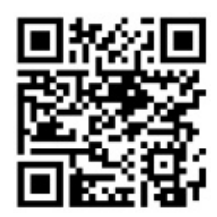

Contact Journal MCD

info@journalmcd.net for general inquiries regarding MCD funding@journalmcd.net to support the journal

Madagascar Conservation \& Development Institute and Museum of Anthropology

University of Zurich

Winterthurerstrasse 190

$\mathrm{CH}-8057$ Zurich

Switzerland

Indian Ocean e-Ink

Promoting African Publishing and Education

www.ioeink.com

Missouri Botanical Garden (MBG)

Madagascar Research and Conservation Program

BP 3391

Antananarivo, 101, Madagascar 
" proposons quelque chose, ils viendront voir » aussi bien pour l'écotourisme, le développement durable que les efforts déployés localement pour la protection de la nature. Les problèmes rencontrés par KOFAMA dans ses efforts pour protéger le Tsingy Mahaloka soulignent l'importance de mener un travail ethnographique et socio-économique détaillé avant d'embarquer dans des efforts de protection de la nature gérés localement.

\section{INTRODUCTION}

Ecotourism aims to achieve three main objectives (Healy 1994, Goodwin 1996, Goodwin and Swingland 1996, Scheyvens 1999 Horwich and Lyon 2007, Kothari et al. 2013, Ardoin et al. 2015): (i) to produce financial support for the establishment, management, and protection of natural areas; (ii) gain economic benefits for residents living near those protected natural areas; and, (iii) out of those economic benefits, produce conservation action that is actively supported by local residents. Additionally, numerous studies are in agreement that in advance of ecotourism projects, best practices should include a detailed socio-economic assessment of the community, or communities, involved in the plan (e.g., Stem et al. 2003, Naughton-Treves et al. 2005, Wilder and Walpole 2008, Kothari et al. 2013, Pullin et al. 2013).

Under Madagascar's National Environmental Action Plan, or NEAP, which ran between 1991 and 2008, major focus was placed on the protection and management of the country's 'nationa heritage' of biodiversity (Mercier 2006). An internationally significant development in Madagascar's NEAP came in 2003 at the Vth World Parks Congress in Durban, South Africa, when thenPresident Marc Ravalomanana made the bold announcement that Madagascar would, by 2008, triple its protected areas system from 1.7 million hectares to 6.0 million hectares (Scally 2006, Dhital et al. 2015). The target of 6.0 million hectares, subsequently referred to as the Durban Vision, would place 10\% of the country's surface area under Madagascar's protected areas system (Scally 2006, Virah-Sawmy et al. 2014). The 'Durban Vision' involved the creation of new national parks and other protected areas. But, a key component of the Durban Vision plan was to also incorporate an extensive program of community-level management into the nation's protected areas system - that is, the creation of numerous Community-Managed Protected Areas, or CMPAs, island-wide (Ferguson 2009). This involved the devolution of control management responsibility for protected areas from the government of Madagascar to local communities, under the jurisdiction of community forest management committees, Vondron' Olona Ifotony or VOI (WRM 2008, Virah-Sawmy et al. 2014, Dhital et al. 2015). One manifestation of this larger national program to utilize community-managed protected areas as a means to increase Madagascar's protected area coverage was a collaborative plan developed in early 2007 between village associations in the rural commune of Antsiravibe and the Peace corps. The plan was to create a community-managed conservation area at a local site known as Tsingy Mahaloka.

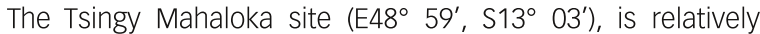
remote, located approximately $15 \mathrm{~km}$ west of the small village of Isesy along Route Nationale (RN) 6, just south of Ankarana National Park. Located adjacent the rural commune of Ampotsehy, Tsingy Mahaloka is an impressive limestone karst massif, or mogote, rising sharply from the coastal plain immediately southwest of Ankarana National Park. Tsingy Mahaloka seemed ideally suited to be a community-managed protected area given its striking topography, diverse endemic avifauna, resident crowned lemur Eulemur coronatus population, and extensive caves containing human burials made over generations. At first blush, the site would appear to offer much for the attraction and education of ecotourists.

In late November of 2007, an 'umbrella association'- dubbed KOFAMA (Koperative Fikambanana Ankarabe Mitsinjo Arivo) was formed, bringing together existing village associations that shared outlooks and activities concerning the preservation of local Malagasy culture and sustainable management of the surrounding environment. The planned goal of the village associations in KOFAMA, through their collaboration with the local Peace Corps volunteer, was to make Tsingy Mahaloka a site for sustainable ecotourism (Turner 2007, Colquhoun et al. 2011). Administrative positions in KOFAMA are held by villagers from the rural commune of Ampotsehy.

In mid-2007 a team of researchers from the University of Western Ontario and the Université d'Antsiranana established links with people in the rural commune of Amposehy and the Peace Corps. In collaboration with the President and VicePresident of KOFAMA and the regional Peace Corps volunteer, the research team made plans to begin fieldwork at Tsingy Mahaloka to study the development of this ecotourist project (Colquhoun et al. 2011). At that time, efforts to attract ecotourists were just beginning. KOFAMA was operating primarily through the voluntary participation of some 20 local residents. Apart from some organizational input from the regional Peace Corps volunteer, KOFAMA had no external assistance or funding. Although the Tsingy Mahaloka site is relatively close to Ankarana National Park, a popular ecotourist destination, the number of ecotourists visiting the Tsingy Mahaloka area in 2007-2008 was only nominal and the site had not been widely advertised to tour guides in the region. However, field school visits to the Tsingy Mahaloka site in 2008, 2010, and 2012 by researchers and students from the University of Western Ontario and Université d'Antsiranana did contribute some income to the members of KOFAMA. In addition, longer term stays by anthropology graduate students conducting both sociocultural and primatological Master's thesis research (2008, 2010, and 2011) also generated revenue to KOFAMA. Beyond outlining the historical background surrounding the formation and development of KOFAMA, the focus of this paper is to highlight the results of a consultative assessment of KOFAMA's state of organization undertaken, with KOFAMA's permission and support, in May and June of 2010 by an international team of anthropologists and primatologists. The main outcome of this collaborative research project was an extensive set of recommendations that were brought forward to the KOFAMA membership, and are presented in this paper. The recommendations include suggested paths to address structural and administrative issues that KOFAMA has experienced, and ways the association can move towards its stated goals of preserving local Malagasy culture and developing sustainable management of the Tsingy Mahaloka site. These details of the 2010 fieldwork with the members of KOFAMA and the residents of the rural commune of Antsiravibe are presented in the broader context of the continuing review of the development of KOFAMA from 2007 to 2013. 


\section{APPROACH}

The research team conducting the 2010 field project on KOFAMA's state of organization brought together collaborators from the Université d'Antsiranana, University of Western Ontario (Canada), University of West Georgia and Eastern Kentucky University (United States), and the Musée du Quai Branly (France). All the non-Malagasy researchers, five in total, were anthropologists (three sociocultural anthropologists, and two primatologists who have both conducted ethnoprimatological research), and all had worked in northern Madagascar since the early 1990s. In collaboration with the KOFAMA executive members (President and Vice-President), we sought to gather perceptions of KOFAMA's efforts at locally-managed conservation from people living adjacent to the Tsingy Mahaloka site. The group also sought to gauge the levels of local involvement and commitment that KOFAMA had been able to muster.

The group was assisted in this collaborative project by a team of ten senior undergraduate students (five anthropology students from University of Western Ontario and five AngloAmerican Studies students from the Universite d'Antsiranana), as well as two Master's students from Western University and two graduate students from Université d'Antsiranana. The research effort was also facilitated by the regional Peace corps volunteer Between 1-14 June 2010, a total of 71 detailed, semi-structured interviews were conducted with adults who had first agreed to be interviewed. All interviews took place at the homes of the interviewees, at multiple sites in the vicinity of the Tsingy Mahaloka site, including the communities of Amposehy, Antsiravibe, and Analasatrana. All interviews were conducted in Malagasy and recorded for later translation. Data collected included basic demographic data (i.e., age and sex of the interviewee), as well as: the individual's place of birth; selfidentification of their Malagasy ethnicity; where their family tombs/burials were located; marital status; level of education, religious affiliation; what traditional fady (i.e., cultural prohibitions, or taboos) they practiced; how they made their livelihood (and if a farmer, what crops they grew and what animals they kept) whether they had ever worked with tourists; whether they knew about, and were a member of, KOFAMA; what they saw as possible benefits of, or problems with, KOFAMA; and, whether they were concerned with tourists (vazaha) possibly transgressing Malagasy customs or fady.

Following the collection of the interview data, translation of the interviews from Malagasy into English was undertaken by the students working in pairs - i.e., one Université d'Antsiranana student from the Anglo-American Studies Program paired with a University of Western Ontario student. By the end of the field course in late June 2010, sufficient translation and preliminary analysis of the interview data had been completed for the five undergraduate student pairs to give a bilingual (Malagasy-English) set of public presentations at the Universite d'Antsiranana. Fina completion of the interview translations was completed at the University of Western Ontario during the fall-winter semesters of 2010-2011 when the two Université d'Antsiranana graduate students who had participated in the fieldwork at KOFAMA came to Canada on exchange.

\section{OUTCOME OF ASSESSMENT}

In June of 2011, an interim report on, and recommendations from, our 2010 field project was delivered to the KOFAMA association members. The Peace Corps volunteer working in the region was also made aware of the report and its recommendations. Our recommendations to the members of KOFAMA included: (i) Make efforts to communicate the existence of Tsingy Mahaloka and the attractions offered there to tour operators in Antsiranana and Nosy Be; (ii) communicate the existence of Tsingy Mahaloka and the goals of KOFAMA to inhabitants of the region through various media including public meetings, radio broadcasts, and visits to schools; (iii) that the goals of KOFAMA be discussed, clarified and/or determined, and that these goals be clearly indicated in written and oral form for the sake of the membership. Regular meetings of the association should occur to ensure that the membership is kept informed of progress towards meeting these goals; (iv) that the members of KOFAMA discuss and develop a clear plan for the management of money generated by the project, with clear guidelines for how this money is to be reinvested, redistributed and saved; (v) that regular communication be maintained with local elders responsible for cultural care of the human remains buried in Mandresibe Cave (at the base of Tsingy Mahaloka) in order to develop and regularly evaluate policies regarding use of this site as an attraction; (vi) that KOFAMA members should discuss, develop, and make known clear policies related to the collection, distribution, and management of money generated by tours of the cave tombs; (vii) that through consultation with local elders and others responsible for this site, KOFAMA members develop a clear, safe and respectful circuit that tourists and guides can consistently follow through the cave - such a circuit should be designed to ensure the well-being of visitors, entombed ancestors and local descendants, and to maintain the integrity of the human remains and cultural material found on site; (viii) that with the assistance of visiting researchers and students, KOFAMA members continue to document, monitor, and publicize the diversity of flora and fauna in and around the community-managed forest; (ix) that KOFAMA members promote conservation of local biodiversity in the managed area and in surrounding communities; and that, $(x)$ KOFAMA members promote the conservation and growth of the community-managed forest by limiting the felling of trees, encouraging fuel wood collection from elsewhere, and planting native species on forest edges.

\section{WHAT WORKED AND WHAT DID NOT WORK, AND WHY}

First and foremost, the collaborative approach taken in the fieldwork conducted at Tsingy Mahaloka since 2007 has been at least of some benefit to all those involved - the researchers, the students, the members of the KOFAMA association, and the Peace Corps Volunteers alike (Colquhoun et al. 2011). This was particularly true in the 2010 field season, where we were able to actively include the field course students in our research project focused on KOFAMA - rather than doing some sort of small-scale project within the field course, the students were able to gain real field research experience and contribute to the KOFAMA research project. The other side of this is that the Student Exchange Agreement between the University of Western Ontario and the Université d'Antsiranana has been a mechanism by which we have been able to provide opportunities for Malagasy students to gain international experience and advance their own research projects. While visiting the Tsingy Mahaloka site, we paid camping fees to the KOFAMA association as well as a daily rate per individual for meals; these funds were shared among the 
members of KOFAMA. Even though it was a drawn-out process, the certification system to gain the KOFAMA association the necessary governmental clearance to assume community management of Tsingy Mahaloka ultimately proved workable. Madagascar's move to use the community management of protected areas as a means to increase the country's tota protected areas system has been criticized (e.g., Gardner (2011) argued that far from being protected areas, Madagascar's new community-managed conservation areas were actually areas that needed protection from people). But, this criticism was largely centered on Madagascar's new system of community-managed protected areas as not aligning with the currently established IUCN categories for protected area status. Presently, the IUCN protected area definition, management categories and governance types encompasses six management categories (Dudley 2008, Rasoavahiny et al. 2008, Dudley et al. 2009). However, Gardner's (2011) criticism of Madagascar's communitymanaged conservation area initiative fails to recognize or acknowledge that these areas can actually encompass multiple IUCN protected area categories. For example, the KOFAMA site as a protected area captures IUCN Category 2 (as an ecotourism site), Category 3 (Tsingy Mahaloka is a sacred site for the local Antankarana people - there are generations old burials in caves deep in the massif; see also Sponsel 2008, Dudley et al. 2009), Category 4 (the massif is the locale of the most southwesternly located population of crowned lemurs in Madagascar; Colquhoun 2011), and Categories 5 and 6 (which address the sustainable use of the Tsingy Mahaloka as a protected area). Indeed, there is now a diverse body of comparative literature on collaboratively managed protected areas (CMPAs) that has established broad agreement on their value (e.g., Kothari 2008, Kothari et al. 2013) and supports the view that a community-managed approach to conservation is certainly something that should be considered as part of a broad-based conservation strategy (see also Reynolds and Bettinger 2008). In terms of monitoring the crowned lemur population resident on Tsingy Mahaloka (Solomon 2009), an especially useful and flexible conceptual framework for considering the potential interactions between the lemurs and people living adjacent to the Tsingy Mahaloka massif is Sponsel's (1997) ethnoprimatological paradigm (see also Estrada 1997). Ethnoprimatology is the field of study that considers the interfaces between human and nonhuman primate ecology; Sponsel (1997) defines ethnoprimatology as encompassing: comparative ecology, predation ecology, synecology, cultural ecology, ethnoecology, and conservation ecology. In the larger context of lemur conservation efforts across Madagascar, the ethnoprimatological paradigm will be a productive tool going forward. Sites such as Tsingy Mahaloka and associations like KOFAMA figure prominently in the new IUCN Lemurs of Madagascar Conservation Action Plan for 2013-2016 (Schwitzer et al. 2013, 2014), which promotes a three-pronged conservation strategy focused on: (i) working closely with local communities and including community-managed protected areas as valid conservation efforts; (ii) promoting lemur ecotourism; and, (iii) maintaining the long-term presence of field researchers at key sites and establishing new research projects on other species and at new sites (Laurance 2013).

While the Tsingy Mahaloka site seemed, initially, to possess qualities that made it a promising candidate for development as an ecotourist site and community-managed conservation area, a combination of factors have so far prevented this potential from being reached. Although Tsingy Mahaloka appeared to be the right place for a community-managed conservation area, events that transpired subsequent to initiating the project in 2007 turned this into a case of it being the wrong time for such a plan. Perhaps the largest impediment to KOFAMA's development was Madagascar's recent political crisis that began to unfold in 2009. Western governments (e.g., France, Great Britain, Canada, the United States) issued travel warnings, advising their citizens against all non-essential travel to Madagascar. Tourist travel to Madagascar plummeted as a result; while 2008 had seen a promising trickle of 'back-pack' ecotourists to Tsingy Mahaloka, in 2009 the site did not record a single ecotourist visitor. The lack of ecotourist traffic continued in 2010 - as mentioned above, when we arrived in late May 2010 to conduct research on the KOFAMA association, we were the first visitors they had received that year. Return visits by members of the University of Western Ontario-Universite d'Antsiranana research team to Tsingy Mahaloka in 2012 and 2013 revealed much the same situation - the ecotourist camping area at the site was becoming overgrown with vegetation and the few buildings at the site were in a state of disrepair.

While the turmoil of Madagascar's political crisis could not have been predicted in 2007, more thorough planning for a community-managed protected area and ecotourist destination at Tsingy Mahaloka may have better-prepared the members of KOFAMA for the difficulties the organization encountered. In hindsight, obtaining detailed socio-economic data (similar to the data we complied in 2010) about the members of KOFAMA and their communities could have contributed to framing the association's long-term strategy (e.g., Stem et al. 2003, NaughtonTreves et al. 2005, Wilder and Walpole 2008, Kothari et al. 2013, Pullin et al. 2013).

The relatively remote location of Tsingy Mahaloka has also proven to be an obstacle to KOFAMA's successful development. The site is only accessible by the dirt track that runs west from RN6 and the village of Isesy. In comparison to the community of Mahamasina, a popular ecotourist destination located along RN6 adjacent to the main entry point to Ankarana National Park, the Tsingy Mahaloka site is difficult to reach. It is also not well-known to tour guides, again in contrast to Mahamasina. While Mahamasina is only about a two-hour drive south of Antsiranana, it takes about an additional hour and a half to get to Tsingy Mahaloka. The tourists that do venture to Tsingy Mahaloka need to be interested in seeking places "off the beaten track". Although a brochure to advertise the Tsingy Mahaloka site was drafted in 2011 (which was one of the recommendations in our preliminary report to KOFAMA), its distribution has been a problem and the Tsingy Mahaloka site still has not been incorporated into the tour packages offered by tour guides in Antsiranana.

Not only have there been numerous reports cautioning that ecotourism may well have only limited or localized economic benefits and impact (e.g., Durbin and Ratrimoarisaona 1996, Stem et al. 2003, Naughton-Treves et al. 2005, Pullin et al. 2013, Gezon 2014, Scales 2014), there have also been several reports that advocate for sound socioeconomic assessments of the involved communities prior to launching a community-managed conservation endeavor, because it is a long-term process (Naughton-Treves et al. 2005, Wilder and Walpole 2008, Kothari et al. 2013, Gezon 2014, Cullman 2015). Preliminary results from our interview data with people living in the vicinity of the Tsingy 
Mahaloka site indicated that the KOFAMA association suffered from a major problem in local recognition. Only 34 of the 71 individuals (47.9\%) interviewed indicated that they had heard of KOFAMA. As for membership in KOFAMA, just eight of the 71 individuals interviewed (11.3\%) were actively involved in the association. Unexpectedly, the interviews also revealed a diversity of ethnic backgrounds among people living in the area, rather than a uniform Antankarana ethnicity (which we had more or less assumed). Individuals in our survey/interview sample selfidentified as belonging to a total of no fewer than 10 different ethnic groups. Migration into the region in the recent past has been due to people seeking employment in the sugar cane industry. We found that a majority of KOFAMA's members had immigrated to the area from other parts of Madagascar. Consequently, there were not the same deep kin connections within the KOFAMA association that typify many other rural Malagasy associations. What people in the KOFAMA association largely have in common is that they all now live in the same area. While this may serve as a basis for forming the association in the first place, it is not a particularly strong basis for maintaining the association. Our interview data also revealed that people were integrated into social networks that involved many organizations of different sorts. Thus, below the surface, KOFAMA faces competition for peoples' time and commitment from other associations and organizations in the area. KOFAMA could find itself squeezed for membership because people in the area may feel that they are already extended in their commitments to other associations.

\section{LESSONS LEARNED}

The development of KOFAMA has relied heavily on the key roles played by a series of Peace Corps volunteers right from the initial formation of the association (Colquhoun et al. 2011). Madagascar's recent political crisis played havoc with the length of interaction, and the continuity, that Peace corps volunteers had with the KOFAMA association (e.g., evacuations of volunteers in 2009 during the political crisis due to the U.S. government's opposition to the High Authority of Transition). This, together with inter-personal issues among KOFAMA members (e.g., matters of trust in the handling and management of KOFAMA funds), has hindered the efficacy of KOFAMA's operation.

Plans to develop Tsingy Mahaloka into an ecotourist destination and the organization of the KOFAMA association departed from the best-practices model of conducting detailed socioeconomic analyses of the communities involved before launching an ecotourist project (Stem et al. 2003, Naughton-Treves 2005, Kothari 2008, Wilder and Walpole 2008, Kothari et al. 2013, Pullin et al. 2013, Gezon 2014, Cullman 2015). Rather, local support for establishment of a protected area was generated, and local expectations raised, ahead of any real tourist traffic to the site. That background context, together with Tsingy Mahaloka's remote location and Madagascar's recent political crisis, has handicapped efforts to establish Tsingy Mahaloka as an ecotourism destination. Despite this, a small core of the KOFAMA association remains committed to achieving some version of the original plan for Tsingy Mahaloka. Based on the track record since KOFAMA's founding, ecotourism does not look like it is a sustainable undertaking at the Tsingy Mahaloka site. Future field research and student excursions could certainly bring more people to this remote area, and revenue to KOFAMA, but this will require a continued high level of institutional support from the participating universities. In 2010-2011 the University of Western Ontario tried to raise funds from alumni to establish a field station at Tsingy Mahaloka, which would have facilitated a continuing research presence there (Laurance 2013, Stroud et al. 2014). Unfortunately, this fund-raising initiative was not successful, and plans for a field station have been shelved for the time being.

It is important to put KOFAMA's history and the stalled ecotourist project at Tsingy Mahaloka into a broader context. Kothari (2008: 31) notes that, "... lack of adequate implementation of the fundamental principles of equitable conservation cannot be seen as a failure of the principles themselves (Brechin et al. 2002, Wilshusen et al. 2002, Spiteri and Nepalz 2006). Moreover, evidence from around the world suggests that new paradigm approaches to conservation (especially co-managed protected areas and community conserved areas) do indeed often work, where implemented with sufficient policy back-up, on-ground capacity, and other key ingredients (see examples in Kothari 2006a, b)." So, while ecotourism and community-based protected area management has not successfully been established at Tsingy Mahaloka, it is worth remembering that across Madagascar there are numerous successful community-managed protected areas, and this will continue to be an important part of the 'tool-kit' for lemur conservation (Schwitzer et al. 2013, 2014). While the final story of KOFAMA and the Tsingy Mahaloka site has yet to be written, the story thus far is certainly a cautionary one. To paraphrase the well-known line from the 1989 film 'Field of Dreams' - even if you build it, they might not come.

\section{ACKNOWLEDGEMENTS}

This project was funded by a Social sciences and Humanities Research Council of Canada International Opportunities Fund grant awarded to Andrew Walsh (Principal Investigator) and Ian Colquhoun (Co-Principal Investigator), SSHRC-IOF grant number 861-2009-1012. This research project had the approval of the University of Western Ontario's Non-Medical Research Ethics Board. Thanks to Andrew Walsh, Lisa Gezon, Laurent Berger, and Ben Freed for their contributions to the fieldwork at Tsingy Mahaloka, and to all the students for their hard work and enthusiasm. Louis-Philippe d'Arvisenet handled the logistical requirements of our research team masterfully. To the Peace corps volunteers who have worked with KOFAMA at different times, a word of appreciation is due - Christi Turner, Julia Nelson, Cori Hinton, Ted Koenig are saluted for their work with the people of the rural communes of Antsiravibe and Ampotsehy. It is worth noting that another hopeful sign going forward is that former Peace Corps volunteers Julia Nelson and Christi Turner have joined forces to establish an NGO named Atsika, which means 'we', or 'us', in the Antankarana dialect; Atsika will endeavor to assist KOFAMA and the people living in the vicinity of Tsingy Mahaloka and aims to develop "... educational opportunities for Malagasy people in the Ankarana community through youth scholarships, adult education, and vocational training focused on the ecotourism sector. Adhering to the principles of sustainable, responsible, community-managed ecotourism, Atsika helps the people of the Ankarana region to improve their lives and the lives of their families, whilst promoting environmental conservation and sustainable income generation." (http://www.atsika.org/index.html). 


\section{REFERENCES}

Ardoin, N. M., Wheaton, M., Bowers, A. W., Hunt, C. A. and Durham, W. H. 2015. Nature-based tourism's impact on environmental knowledge, attitudes, and behavior: a review and analysis of the literature and potential future research. Journal of Sustainable Tourism 23, 6: 838-858. (doi:10.1080/09669582.2015.1024258)

Brechin, S. R., Wilshusen, P. R., Fortwangler, C. L. and West, P. C. 2002. Beyond the square wheel: Toward a more comprehensive understanding of biodiversity conservation as social and political process. Society and Natural Resources 15, 1: 41-64. (doi:10.1080/089419202317174011)

Colquhoun, I. C. 2011. Establishing the southwestern limits in the geographic distributions of Eulemur coronatus and $E$. sanfordi. Paper presented at the 38th Annual Meeting of the Canadian Association for Physical Anthropology (CAPA-ACAP), Saskatoon, Saskatchewan, 27-30 October 2011.

Colquhoun, I. C., Totomarovario, A. and Walsh, A. F. 2011. Good neighbors. Anthropology News 52, 9:7.

Cullman, G. 2015. Community forest management as virtualism in northeastern Madagascar. Human Ecology 43, 1: 29-41. (doi:10.1007/s10745-015-9725-5)

Dhital, N., Rasoloarisoa Vololomboahangy, R. and Khasa, D. P. 2015. Issues and challenges of forest governance in Madagascar. Canadian Journal of Development Studies / Revue canadienne d'études du développement 36 1: 38-56. (doi:10.1080/02255189.2015.989197)

Dudley, N. (ed.) 2008. Guidelines for Applying Protected Area Management Categories. IUCN, Gland, Switzerland. Available at <https://goo.gl/e064W6>

Dudley, N., Higgins-Zogib, L. and Mansourian, S. 2009. The links between protected areas, faiths, and sacred natural sites. Conservation Biology 23, 3: 568-577. (doi:10.1111/j.1523-1739.2009.01201.x)

Durbin, J. and Ratrimoarisaona, S.-N. 1996. Can tourism make a major contribution to the conservation of protected areas in Madagascar? Biodiversity and Conservation 5. 3: 345-353. (doi:10.1007/BF00051778)

Estrada, A. 1997. Book Review: New World Primates. International Journal of Primatology 18, 6: 1047-1049. (doi:10.1023/A:1026308516556)

Ferguson, B. 2009. REDD comes into fashion in Madagascar. Madagascar Conservation \& Development 4, 2: 132-137. (doi:10.4314/mcd.v4i2.48654)

Gardner, C. 2011. IUCN management categories fail to represent new multiple-use protected areas in Madagascar. Oryx 45, 3: 336-346. (doi:10.1017/S0030605310001808)

Gezon, L. L. 2014. Who wins and who loses? Unpacking the "Local People" concept in ecotorism: A longitudinal study of community equity in Ankarana, Madagascar. Journal of Sustainable Tourism 22, 5: 821-838. (doi:10.1080/09669582.2013.847942)

Goodwin, H. 1996. In pursuit of ecotourism. Biodiversity \& Conservation 5, 3 277-291. (doi:10.1007/BF00051774)

Goodwin, H. J. and Swingland, I. R. 1996. Ecotourism, biodiversity and local development. Biodiversity and Conservation 5, 3: 275-276. (doi:10.1007/BF00051773)

Healy, R. G. 1994. Tourist merchandise as a means of generating local benefits from ecotourism. Journal of Sustainable Tourism 2, 3: 137-151. (doi:10.1080/09669589409510691)

Horwich, R. H. and Lyon, J. 2007. Community conservation: practitioner's answer to critics. Oryx 41, 3: 376-385. (doi:10.1017/S0030605307001010)

Kothari, A. 2006a. Collaboratively managed protected areas. In: Managing Protected Areas: A Global Guide, I. Lockwood, G. Worboys, G. and A. Kothari (eds.), pp. 528-548. IUCN, Gland, Switzerland and Earthscan, London.

Kothari, A. 2006b. Community conserved areas. In: Managing Protected Areas: A Global Guide, I. Lockwood, G. Worboys, G. and A. Kothari (eds.), pp 549-573. IUCN, Gland, Switzerland and Earthscan, London.

Kothari, A. 2008. Protected areas and people: the future of the past. Parks 17, 2 : 23-34. Available at <http://goo.gl/J5amjD>

Kothari, A., Camill, P. and Brown, J. 2013. Conservation as if people also mattered: Policy and practice of community-based conservation. Conservation \& Society 11, 1: 1-15. (doi:10.4103/0972-4923.110937)

Laurance, W. F. 2013. Does research help to safeguard protected areas? Trends in Ecology \& Evolution 28, 5: 261-266. (doi:10.1016/j.tree.2013.01.017)
Mercier, J.-R. 2006. Madagascar moving towards sustainable development: was the preparation of the National Environmental Action Plan (NEAP) a false start? Madagascar Conservation \& Development 1, 1: 50-54 (doi:10.4314/mcd.v1i1.44122)

Naughton-Treves, L., Holland, M. B. and Brandon, K. 2005. The role of protected areas in conserving biodiversity and sustaining local livelihoods. Environment and Resources 30: 219-252. (doi:10.1146/annurev.energy.30.050504.164507)

Pullin, A. S., Bangpan, M., Dalrymple, S., Dickson, K., Haddaway, N. R., et al. 2013. Human well-being impacts of terrestrial protected areas. Environmental Evidence 2013 2: 19. (doi:10.1186/2047-2382-2-19)

Rasoavahiny, L., Andrianarisata, M., Razafimpahanana, A., Ratsifandrihamanana, A. N. 2008. Conducting an ecological gap analysis for the new Madagascar protected area system. Parks 17, 1: 12-21.

Reynolds, V. and Bettinger, T. 2008. Guidelines for Conservation Through Community Involvement. Position Statement of the International Primatological Society. Available at <http://goo.gl/mzTZXV>

Scales, I. R. 2014. The future of conservation and development in Madagascar: time for a new paradigm? Madagascar Conservation \& Development 9, 1 5-12. (doi:10.4314/mcd.v9i1.2)

Scally, R. 2006. Biodiversity: Expanding Madagascar's national parks and protected areas. In: GIS for Environmental Management. R. Scally (ed.), pp 1-15. ESRI Press, Redlands, California.

Scheyvens, R. 1999. Ecotourism and the empowerment of local communities. Tourism Management 20, 2: 245-249. (doi:10.1016/S0261-5177(98)00069-7)

Schwitzer, C., Mittermeier, R. A., Davies, N., Johnson, S. E., Ratsimbazafy, J., et al. (eds.), 2013. Lemurs of Madagascar: A Strategy for Their Conservation 2013-2016. IUCN/SSC Primate Specialist Group, Bristol Conservation and Science Foundation, and Conservation International, Bristol, UK.

Schwitzer, C., Mittermeier, R. A., Johnson, S. E., Donati, G., Irwin, M., et al. 2014. Averting lemur extinctions amid Madagascar's political crisis. Science 343, 6173: 842-843. (doi:10.1126/science.1245783)

Solomon, S. 2009. Living on the edge: A preliminary dry season study of crowned lemur (Eulemur coronatus, Gray 1842) and Sanford's lemur (E. sanfordi, Archbold 1932) responses to anthropogenic habitat changes in northern Madagascar. Unpubl. Master thesis, Western University, London, Canada.

Spiteri, A. and Nepalz, S. K. 2006. Incentive-based conservation programs in developing countries: A review of some key issues and suggestions for improvements. Environmental Management 37, 1: 1-14. (doi:10.1007/s00267-004-0311-7)

Sponsel, L. E. 1997. The human niche in Amazonia: Explorations in ethnoprimatology. In: New World Primates: Ecology, Evolution, and Behavior, W. G. Kinzey (ed.), pp 143-165. Aldine de Gruyter, New York.

Sponsel, L. E. 2008. Sacred Places and Biodiversity Conservation. <http://goo.gl/WFPpTe> accessed 10 March 2015

Stem, C. J., Lassoie, J. P., Lee, D. R., Deshler, D. D. and Schelhas, J. W. 2003. Community participation in ecotourism benefits: The link to conservation practices and perspectives. Society \& Natural Resources 16, 5: 387-413. (doi:10.1080/08941920309177)

Stroud, J. T., Rehm, E., Ladd, M., Olivas, P. and Feeley, K. J. 2014. Is conservation research money being spent wisely? Changing trends in conservation research priorities. Journal for Nature Conservation 22, 5: 471-473. (doi:10.1016/j.jnc.2014.05.003)

Turner, C. 2007. Community Ecotourism in the Ankarana Region, Madagascar. Creating a new route in collaboration with the local population. Unpub. planning document prepared for the Rural Commune of Antsiravibe and the Peace Corps.

Virah-Sawmy, M., Gardner, C. J. and Ratsifandrihamanana, A. N. 2014. The Durban Vision in practice: Experiences in the participatory governance of Madagascar's new protected areas. In: Conservation and Environmental Management in Madagascar. I. R. Scales (ed.), pp 216-251. Routledge, London.

Wilder, L. and Walpole, M. 2008. Measuring social impacts in conservation: experience of using the most significant change method. Oryx 42, 4: 529-538. (doi:10.1017/S0030605307000671) 
Wilshusen, P. R., Brechin, S. R., Fortwangler, C. L. and West, P. C. 2002. Reinventing a square wheel: Critique of a resurgent "protection paradigm" in

international biodiversity conservation. Society \& Natural Resources 15,1 17-40. (doi:10.1080/089419202317174002)

WRM (World Rainforest Movement). 2008. The Impact of Forest Conservation Policies on Forest Dependent Communities in SE Madagascar: Lessons for Sustainability of Madagascar's New Protected Areas. WRM Bulletin 133. <http://goo.gl/u94vJt> accessed 10 March 2015 